\title{
C ++ for Cloud Computing Application in Elementary Schools on Covid-19 Pandemics
}

\author{
Ferril Irham Muzaki ${ }^{1, *}$ \\ ${ }^{I}$ Department of Primary and Childhood Education, Faculty of Education, Universitas Negeri Malang, Malang, Indonesia \\ *Corresponding author. Email: ferril.irham.fip@um.ac.id
}

\begin{abstract}
The development of Information and Communication Technology (ICT) today has had a broad impact on individuals involved in teaching and learning activities in the elementary school environment. In these development activities, the determination of social distancing is put forward in order to prevent Covid 19 from taking place and infecting other individuals. For this reason, this review article discusses more about the use of $\mathrm{C}++$ based programming to design cloud-based applications that prioritize programmer skills combined with collaboration with teachers as application developers. Integration between teachers and application developers is the starting point of application development that provides opportunities for students to interact with activities that open up opportunities in the user experience to create skills and ease of use with user friendly principles. To develop this capability, an integration between C ++ and Php My Admin is needed which is related to the skills to make application design easier by using the notepad application that is built in various types of operating system applications both Windows and Linux.
\end{abstract}

Keywords: information and communication technology, $\mathrm{C}++$, apps builder, cloud computing

\section{INTRODUCTION}

The development of information and communication technology provides opportunities for teachers to convey learning openly. Walnum and Andrae (2016) describe learning at this time, a teacher has challenges in the form of developing adequate media and learning resources optimally. In this case, a teacher has a challenge in the form of developing teaching materials that adapt to individual skills and abilities to collaborate in various scientific fields, which means the use of cloud computing.

Warren and Skillman (2020) view that the ability of a student in primary school before 2020 focuses more on learning based on developing adequate knowledge with face-to-face learning in an elementary school environment. The focus of the problem during the Covid-19 pandemic is a dominant challenge, given the various kinds of individuals despite trying to maintain physical distance. The challenge of maintaining physical distance needs to be addressed by designing a learning process that remains interactive but takes into account elements of parallelism and adequate skills in developing an interactive learning process.

The development of cloud computing-based programs as part of the Internet of Things (IOT) is an integral part of the development of the learning process in elementary school environments. An elementary school teacher in overcoming learning conditions that do not allow face-to-face even though he focuses on developing learning designs based on algorithms that are easily designed and identified, namely $\mathrm{C}++. \mathrm{C}++$-based algorithm development is an attempt to develop creativity in collaboration-based cloud computing development with application builders.

The implication of developing adequate learning is programming performance design, the meaning of this implication is that teachers in elementary schools become designers of programming algorithms with the $\mathrm{C}++$ programming language that are integrated with cloud computing applications. The impact of developing this application is mainly from the ability of elementary school teachers to develop independent and measurable learning applications. Primary school teachers are not too dependent on applications from third parties which are prone to intercepting actions and other actions that lead to activities that harm the privacy of elementary school students and official data.

Based on the conditions described above, this article will review algorithms that can be used as a logical basis in developing applications collaboratively together with application builders with the $\mathrm{C}++$ programming language. The algorithm developed is as follows, namely: (1) recursion; (2) logical; (3) serial; parallel or distributed; (4) deterministic or non-deterministic; (5) exact or approximate; and (6) quantum. This review article is expected to provide input for policy makers to develop the independence of teachers in elementary schools in developing self-made applications that can maintain the smoothness of the teaching and learning process in the elementary school environment. 


\section{PLANTING THE CONCEPT OF OPEN SOURCES FOR ELEMENTARY SCHOOL TEACHERS}

Lopez (2019) argues that designing programming concepts, the real conditions faced today are more focused on abilities and skills in understanding the concept of adequate use. To develop programming skills, a teacher, although mastering the basics of concepts with regard to open source-based applications, which are currently mostly developed based on.

Planting the open source concept for elementary school teachers is needed to equip teachers to be more skilled in operating open source tools. In this context, understanding the concept of open sources is the main basis for developing the ability to create an application design. An explanation of the advantages of open source applications compared to closed source applications can be seen in the Table 1.

Table 1 The Advantages of Open Source Applications

\begin{tabular}{|c|l|l|}
\hline No. & \multicolumn{1}{|c|}{$\begin{array}{c}\text { Open Sources } \\
\text { Application }\end{array}$} & Closed Sources Applications \\
\hline 1 & $\begin{array}{l}\text { Can be developed in a } \\
\text { structured manner and } \\
\text { follow technological } \\
\text { developments }\end{array}$ & $\begin{array}{l}\text { Waiting for the initiative from } \\
\text { the factory }\end{array}$ \\
\hline 2 & $\begin{array}{l}\text { Can be developed } \\
\text { according to ability and } \\
\text { programmer }\end{array}$ & $\begin{array}{l}\text { Only affiliated programmers } \\
\text { are allowed to develop } \\
\text { applications }\end{array}$ \\
\hline 3 & $\begin{array}{l}\text { Programmer can share } \\
\text { information regarding } \\
\text { source code }\end{array}$ & $\begin{array}{l}\text { Closed by the factory } \\
\text { exploration without the } \\
\text { involvement of the factory }\end{array}$ \\
\hline 5 & $\begin{array}{l}\text { Application development is } \\
\text { not bound by the copyright } \\
\text { of an application }\end{array}$ & $\begin{array}{l}\text { Copyright bound } \\
\text { writing }\end{array}$ \\
\hline 6 & $\begin{array}{l}\text { Spare parts providers can } \\
\text { be from various sources }\end{array}$ & Must follow the factory \\
\hline 7 & $\begin{array}{l}\text { Human resources can be } \\
\text { directed for improvement } \\
\text { independently }\end{array}$ & $\begin{array}{l}\text { Requires a license from the } \\
\text { manufacturer }\end{array}$ \\
\hline
\end{tabular}

Open source-based applications are more widely applied to the education environment, especially at the primary school level, by teachers who put more emphasis on developing skills for designing. Algorithm design is closely related to the development of individual skills and abilities in developing the diagrammatic direction of an application.

Fua and Lis (2020) have a view that open sourcebased applications that are currently being developed need to be designed in relation to the abilities of each individual. For this reason, open source applications for elementary teachers are designed according to the times that currently need adjustments, especially with regard to $\mathrm{C}++$-based Cloud Computing. The ability to design open source applications can be seen in the Figure 1 .

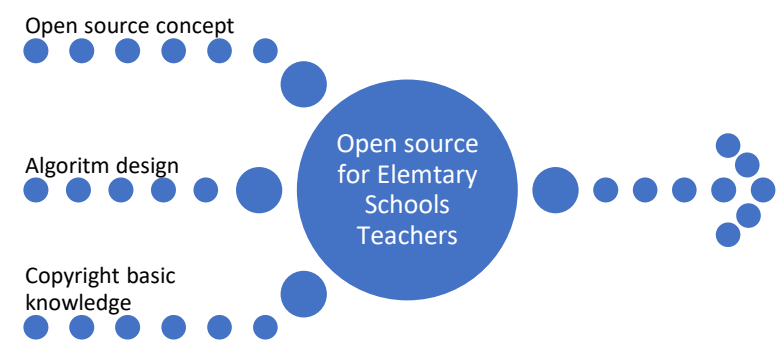

Figure 1 The Ability to Design Open Source Applications

O'Regan (2018) the existence of open source applications, so even though a teacher learns to develop optimal characteristics and knowledge. In this case, the skills to understand the basic concepts of open source applications are a prerequisite for developing $\mathrm{C}++-$ based cloud computing in an elementary school environment. With the development of open source-based applications, it is hoped that a teacher in an elementary school will have sufficient space to develop an application based on open sources based on $\mathrm{C}++$ programming.

Applications for the development of open source device designs are more focused on individual development and design to design the quality of learning to be more interactive by focusing on students. In this case a teacher at the primary school level, although dealing with skills in designing designs for an adequate learning process.

\section{PROGRAMMING LANGUAGE FOR ELEMENTARY SCHOOL TEACHERS}

O'Regan (2018) believes that the basic concept of user experience (UX) in learning in elementary schools is an effort to improve the quality of applications run by each individual related to designing creative steps to improve the skills and abilities of teachers in making designs. application. To design a qualified application, a design is needed that provides data and construction knowledge of the process of the application design.

One example of a modern application design is an application designed to facilitate related individuals in carrying out educational design activities. One of the efforts made is to use the $\mathrm{C}++$ programming language which means the ease of designing user-friendly programming. The advantages of $\mathrm{C}++$ compared to the Pascal programming language can be seen in the Table 2.

Xiduo, et al (2020) have the view that with Pascal programming, the $\mathrm{C}++$ programming language can be applied to teachers in elementary schools as long as they have sufficient mathematical skills and knowledge. Sufficient knowledge of mathematics consists of knowledge of fuzzy logic and neural programming. Pascal based programming languages tend to be used more for programmers who have adequate knowledge of English. 
Table 2 The Advantages of $\mathrm{C}++$

\begin{tabular}{|c|c|c|}
\hline No & $\mathrm{C}++$ & Pascal \\
\hline 1 & $\begin{array}{l}\text { Using universal symbols } \\
\text { such as \&\&, etc. }\end{array}$ & $\begin{array}{l}\text { Using symbol language such as } \\
\text { and, or etc. }\end{array}$ \\
\hline 2 & Sensitive to code changes & $\begin{array}{l}\text { Has flexibility in language } \\
\text { development }\end{array}$ \\
\hline 3 & Syntax based & $\begin{array}{l}\text { Type based to initiate a } \\
\text { command }\end{array}$ \\
\hline 4 & $\begin{array}{l}\text { Programming commands in } \\
\text { mathematical symbols }\end{array}$ & $\begin{array}{l}\text { Instruction instructions in } \\
\text { English }\end{array}$ \\
\hline 5 & $\begin{array}{l}\text { Developed with the notepad } \\
\text { that comes with every laptop }\end{array}$ & $\begin{array}{l}\text { Requires specific applications } \\
\text { that must be downloaded first, } \\
\text { namely notepad }++ \text { and so on }\end{array}$ \\
\hline
\end{tabular}

From here, a synthesis can be drawn to practice $\mathrm{C}++$ programming skills, which requires adequate knowledge and constructs of algebraic and calculus-based theories, in contrast to Pascal programming which puts forward programming in English. The programmer's ability in $\mathrm{C}++$ programming can be explained in the chart below (Figure 2 ). With mastery of the $\mathrm{C}++$ programming language, it is hoped that mastery of the programmer's abilities and skills can be implemented considering that $\mathrm{C}++$ focuses more on universal symbolic language.

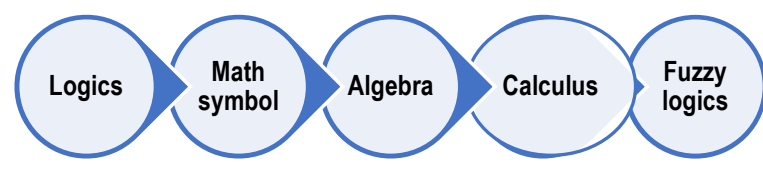

Figure 2 The Programmer's Ability in C ++ Programming

\section{USER EXPERIENCE IN THE}

DEVELOPMENT OF INTERACTIVE CLOUD COMPUTING APPLICATIONS

\section{BASED ON C ++ IN ELEMENTARY SCHOOLS}

Nechesov (2019) have the view that an application even though it is designed to facilitate the use of information and communication technology. In line with these principles, the design of $\mathrm{C}++$-based application tools even though it adapts to the user's conditions, namely teachers who teach in elementary schools. The user as the service user even though they are involved in testing the use of the $\mathrm{C}++$-based application that interacts directly with cloud computing.

In terms of developing the capabilities and skills of an application user, the design of User Expiration, even though it is associated with the use of services, which facilitates user-to-peer interaction, which means adequate design utilization. The difference between user interface and user experience can be seen in the Table 3 .

Petersonet, et all (2019) explain that the use of C ++based designs that prioritizes algorithm-based design which is integrated in Php My Admin, C ++ design even though puts forward the principle of user friendly, which is friendly with users. In utilizing this, the designer even builds an interface that prioritizes ease of operation and cultural closeness with the operating party. This is even though the background for the various steps that provide opportunities for exploration and design to suit the behavior of the program itself.

Table 3 The Difference between User Interface and User Experience

\begin{tabular}{|c|l|l|}
\hline No & \multicolumn{1}{|c|}{ User Interface } & \multicolumn{1}{c|}{ User Experience } \\
\hline 1 & Focus on engineering skills & Focus on design \\
\hline 2 & More on graphic display & Think on user convenience \\
\hline 3 & $\begin{array}{l}\text { The strength of application } \\
\text { lies in skills and design }\end{array}$ & $\begin{array}{l}\text { Act measured and organized } \\
\text { in a design }\end{array}$ \\
\hline 4 & $\begin{array}{l}\text { The application is designed to } \\
\text { approach multitasking }\end{array}$ & Focus more on one design job \\
\hline 5 & $\begin{array}{l}\text { Has a focus and starting point } \\
\text { on syntax }\end{array}$ & Focus on governance \\
\hline 6 & Ability to write absolute code & Based on graphic design skills \\
\hline 7 & $\begin{array}{l}\text { Become a measure of the } \\
\text { ability of a programmer }\end{array}$ & $\begin{array}{l}\text { Be part of a teamwork with } \\
\text { app developers }\end{array}$ \\
\hline
\end{tabular}

Jungblut, Kowalewski and Fürlinger (2018) views C ++ needs to prioritize abilities and skills that provide opportunities for related individuals to prioritize operator skills in designing applications, which means the involvement of elements in the primary school where the application is designed. To design an application, drastic steps are needed that play a role in developing information and communication technology tools based on Cloud Computing. The ability to design UX-based cloud applications in elementary schools can be explained in the chart below (Figure 3).

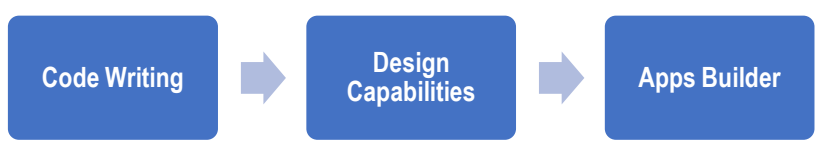

Figure 3 The Ability to Design UX-Based Cloud Applications in Elementary Schools

Fua and Lis (2020) view the design and integration of computer services, even though each individual puts forward the principle of ability that adapts to the skills of using an application. This is where the role of the $\mathrm{C}++$ application is easier to compile if you use Notepad, which is the default application for every Windows application. Designing a user experience for developing $\mathrm{C}++$ applications is part of making it easier for users.

\section{CONCLUSION}

The use of cloud-based programming design using $\mathrm{C}$ ++ is the basics of a programming language. In terms of designing programming, programming language designers, even though they adjust to the teacher's ability to operate the program. The programming base uses a notepad application that has been built in, especially for compiling source code. 
For this reason, the involvement of $\mathrm{C}++$-based cloud application users are needed in terms of designing user experience designs to have better capabilities, namely having user friendly capabilities. The teacher and the programmer carry out application design while for $\mathrm{C}++$ coding uses coding application design. In the case of $\mathrm{C}++-$ based application design, a teacher interacts directly with the programmer which provides direct benefits in terms of making the application more user-friendly.

\section{REFERENCES}

[1] Fua, P., \& Lis, K. (2020). Comparing Python, Go, and C++ on the N-Queens Problem. arXiv preprint arXiv:2001.02491.

[2] Jungblut, P., Kowalewski, R., \& Fürlinger, K. (2018, June). Source-to-Source Instrumentation for Profiling Runtime Behavior of $\mathrm{C}++$ Containers. In 2018 IEEE 20th International Conference on High Performance Computing and Communications; IEEE 16th International Conference on Smart City; IEEE 4th International Conference on Data Science and Systems (HPCC/SmartCity/DSS) (pp. 948953). IEEE.

[3] Lopez, R. (2019). Flood. An open source neural networks $\mathrm{C}++$ library. Monograph CIMNE.

[4] Nechesov, A. (2019). Delta--new logic programming language and Delta-methodology for p-computable programs on Turing Complete Languages. arXiv preprint arXiv:1907.07767.

[5] O'Regan, G. (2018). C and C++ Programming Languages. In the Innovation in Computing Companion (pp. 63-68). Springer, Cham.

[6] Peterson, C., Saddler, J., Blascheck, T., \& Sharif, B. (2019, May). Visually analyzing students' gaze on $\mathrm{C}++$ code snippets. In 2019 IEEE/ACM 6th International Workshop on Eye Movements in Programming (EMIP) (pp. 18-25). IEEE.

[7] Walnum, H. J., \& Andrae, A. S. (2016). The internet: Explaining ICT service demand in light of cloud computing technologies. In Rethinking Climate and Energy Policies (pp. 227-241). Springer, Cham.

[8] Warren, M. S., \& Skillman, S. W. (2020). Mobility changes in response to COVID-19. arXiv preprint arXiv:2003.14228.

[9] Xiduo, W., Jialin, L., \& Zhizhen, Z. (2020, August). Sustainable C++ Education in General High School: from Teaching Programming Skills to Developing Computational Thinking. In 2020 15th International Conference on Computer Science \& Education (ICCSE) (pp. 35-38). IEEE.

[10] Gunawan, I. (2017). Instructional Leadership Profile of Junior High School's Principal (A Case Study of Junior
High School in Malang). International Research-Based Education Journal, 1(1), 64-68.

[11] Gunawan, I. (2018). The Implementation of Lesson Study Based Learning Management and the Effect toward Students' Activeness in Lecturing. JPP (Jurnal Pendidikan dan Pembelajaran), 24(2), 51-63.

[12] Kusumaningrum, D. E., Sumarsono, R. B., \& Gunawan, I. (2018, October). Empowering the Principal of Boarding House-Based Junior High School in East Java Province Indonesia. In 3rd International Conference on Educational Management and Administration (CoEMA 2018). Atlantis Press.

[13] Nurabadi, A., Sucipto, S., Juharyanto, J., \& Gunawan, I. (2018, October). The Implementation of Education Management Standards in the School Laboratory State University of Malang for Improving Educational Quality. In 3rd International Conference on Educational Management and Administration (CoEMA 2018). Atlantis Press.

[14] Gunawan, I. (2016). Perspectives of Pancasila: Leadership Education's Values and Ethics'. 2nd ICET Theme:"Improving the Quality of Education and Training Through Strengthening Networking, 417.

[15] Gunawan, I. I. (2017, August). The Application of Instructional Management Based Lesson Study and its Impact with Student Learning Achievement. In 2nd International Conference on Educational Management and Administration (CoEMA 2017). Atlantis Press.

[16] Bafadal, I., Nurabadi, A., \& Gunawan, I. (2018, December). The Influence of Instructional Leadership, Change Leadership, and Spiritual Leadership Applied at Schools to Teachers' Performance Quality. In International Conference on Education and Technology (ICET 2018). Atlantis Press.

[17] Sultoni, S., Gunawan, I., \& Ningsih, S. O. (2018, October). Descriptive Study of Efforts Integrates Character Values to Students. In 3rd International Conference on Educational Management and Administration (CoEMA 2018). Atlantis Press.

[18] Gunawan, I., Kusumaningrum, D. E., Triwiyanto, T., Zulkarnain, W., \& Nurabadi, A. (2018, October). Hidden Curriculum and its Relationship with the Student Character Building. In 3rd International Conference on Educational Management and Administration (CoEMA 2018). Atlantis Press.

[19] Bafadal, I., Juharyanto, J., Nurabadi, A., \& Gunawan, I. (2018, October). Principal Leadership and its Relationship with Student Learning Achievements: A Regression Analysis. In 3rd International Conference on Educational Management and Administration (CoEMA 2018). Atlantis Press.

[20] Andriningrum, H., \& Gunawan, I. (2018, December). Cultivatation of Healthy Life for Students in School: A Literature Review. In International Conference on Education and Technology (ICET 2018). Atlantis Press. 